Saeculum Christianum

vol. XXIV (2017)

pp. $163-171$

ANNA SYLWIA CZYŻ

Faculty of Historical and Social Sciences

Cardinal Stefan Wyszyński University in Warsaw

\title{
THE CHAPELS OF SAINT CASIMIR AND THE IMMACULATE CONCEPTION AT THE VILNIUS CATHEDRAL IN THE EYES OF DISCALCED CARMELITE NUNS: AN UNRECOGNIZED SOURCE FROM 1638
}

On November 16, 1638, four nuns: Prioress Euphrasia of St.Hyacinth (Teodora Piaseczyńska, d. 1648), Sister Angelica of the Holy Sacrament (Elżbieta Filipowicz, d. 1663), Sister Mary Magdalene of Christ the Redeemer (Anna Żaboklicka, d. 1677), and Sister Anne of St. Bartholomew (Anna Łęcka, d. 1677) ${ }^{1}$ set out on a journey from St. Joseph's Cloister in Lublin to Vilnius ${ }^{2}$, where they were to settle at a new convent founded by the Lithuanian Deputy Chancellor of the Treasury, Stefan Pac (1587-1640), and his wife Anna Maria Ancilla (née Rudomina-Dusiatska, d. 1643) ${ }^{3}$. The route of their journey, along with the accompanying events, such as the perilous river crossings, ${ }^{4}$ as well as the nuns' observations on the

\footnotetext{
1 Lęcka replaced Sister Anne of St. Bartholomew (Zuzanna Włodarz, b. 1587), who fell ill while travelling from Krakow to Lublin, and died soon after (September 28, 1638). See Kronika klasztoru Karmelitanek Bosych pw. św. Józefa w Lublinie, ed. Cz. Gil, Poznań 2012, pp. 77-78; idem, Karmelitanki bose w Polsce, Kraków 2011, p. 42. Conversely, K. Targosz's Piórem zakonnicy. Kronikarki w Polsce XVII w. o swoich zakonach i swoich czasach, Kraków 2002, pp. 90-91, contains inaccurate information on Włodarzówna and the travelling nuns' relations with the Krakow and Lublin convents.

2 The first two were professed nuns at St. Martin's Cloister in Krakow, while the latter two were professed members of the Lublin convent. See Cz. Gil, Slownik polskich karmelitanek bosych 1612-1914, Kraków 1999, p. 22-25, 60-61, 65; idem, Karmelitanki bose ..., op. cit., p. 41 .

3 For more on the foundation of the convent by, and the artistic patronage of, Stefan Pac, see A.S. Czyż, Fundacje artystyczne rodziny Paców: Stefana, Krzysztofa Zygmunta i Mikołaja Stefana Paców. „Lilium bonae spei ab antiquitate consecratum ", Warszawa 2016, pp. 38-154.

4 Just outside of Bielsk Poldkaski, which the nuns left on St. Cecilia's Day, i.e. on Monday, November 22 [...], through a bridge outside of town, which we had to cross, and which was in a poor condition, impeding our crossing and greatly endangering us all (Archives of the Discalced Carmelite Nuns in Wesoła Street, Krakow - hereinafter AKB - AKB 255, sheet 53r). Having passed Sokółka on the morning of Friday, November 26, we rose before daybreak, and resumed our journey against heavy and chilly wind and with frost all around us. The road was blown over with snow, and we struggled to find our way (AKB 255, sheet 56r). In the Polish version of this study, the quotations from the diary were compiled based on the transcription guidelines for historical sources written before the mid-1 $8^{\text {th }}$ century (version B). At the same time, the diarist's idiosyncrasies, including her consistent use of the adjective "wiliński" instead of "wileński" with reference to the city of Vilnius. Authorial interjections and explanations of the abbreviations used by the diarist are put in square parenthesis. See A.S. Czyż, Kaplice św. Kazimierza i Niepokalanego Poczęcia Najświętszej Maryi Panny przy katedrze wileńskiej oczami karmelitanek bosych - nierozpoznane źródło z 1638 r "Saeculum Christianum" vol. XXIV (2017), pp. 162-169.
} 
surrounding world, including Lithuania ${ }^{5}$ - which was completely alien to them - have survived in a rigidly kept diary written by Sister Mary Magdalene of Christ the Redeemer ${ }^{6}$, titled Opisanie poczatków fundacjej wilińskiej [!] karmelitanek bosych pod tytułem Ś[w]. O[jca] N[aszego] Józefa R[oku] P[ańskiego] 1638. Dnia 18 Grudnia.

Sister Mary Magdalene kept a regular diary from November 14, 1638, i.e. the arrival of the Lithuanian Deputy Chancellor of the Treasury and his wife in Lublin ${ }^{7}$, through December 21 that same year, which marked the end of the nuns' introduction to the Vilnius convent. The diary was later redacted, as the author returned to the events that had transpired after the nuns' departure from Lublin ${ }^{8}$. In 1727, the final version of the chronicle was entered in Księga fundacji klasztorów karmelitanek bosych prowincjej polskiej Ducha Św[iętego] od Roku Pańskiego 1612 by the copyist, Sister Cecilia Theresa of the Presentation of the Blessed Virgin Mary (Anna Petronela Zacherla). Ksiega... was subsequently kept at the Convent of St. Thérèse of Lisieux and St. John of the Cross in Wesoła Street, Krakow. The diary begins on page 46 recto and concludes on page 90 verso ${ }^{9}$.

On the following pages of her diary, Sister Mary Magdalene not only enumerated the towns through which they had passed en route to Vilnius (a.o. Lubartów, Czemierniki, Wohyń, Piszczec, Bielsk Podlaski, Choroszcz, Białystok, Sokółka, Labno, Leipalingis,

\footnotetext{
5 While passing the town of Labno on September 26, [the Discalced Carmelites of Vilnius] told us to lift our veils slightly to behold a giant loaf of black bread [...]. They told us, however, that it was not quite the black bread they knew, as the loaf was not as dark as it should have been (AKB 255, sheet 56v). Staying at an inn the following day, we have also got a taste of kvas, which the friars used to wash down black bread, as they could not swallow it without washing it down with the said kvas (AKB 255, sheet. 58r). On their first encounter with the Lithuanian language, the nuns found it highly unintelligible to us, as she [a girl they ran into in Seirijai on November 29] told us their appellations of various objects (AKB 255, sheet $61 \mathrm{v})$.

6 The diarist was first identified by Karolina Targosz (K. Targosz, op. cit., p. 91), who also published a selection of excerpts from the diary and briefly recounted the journey undertaken by the four Discalced Carmelite nuns. At the same time, she did not avoid mistakes when deciphering the names of the towns en route to Vilnius (K. Targosz, op. cit., p. 91: Horoszcz instead of Choroszcz, Prępy instead of Preny [now Prienai]). To be fair, the diarist (and the copyist who rewrote the original text) found it difficult to write them down appropriately, too (see AKB 255, sheet 50r). Karolina Targosz's publication was preceded by a modest (and highly arbitrary) selection of excerpts from the said diary, compiled by Rafał Kalinowski in the first volume of his Klasztory karmelitanek bosych w Polsce, na Litwie i Rusi. Ich początek, rozwój i tułactwo w czasie rozruchów wojennych w XVII w. Rzecz osnuta na kronikach klasztornych, Kraków 1900.
}

7 Stefan and Anna Pac accompanied the nuns for the first two days of their journey, and rejoined them in the town of Prienai.

8 Recalling their preparations for the journey, Sister Mary Magdalene wrote of the aforementioned nun from Krakow, sister Anne of St. Bartholomew. However, recorded the diarist in an entry dated November 14, 1638, according to the ordinance of God [...] she fell ill while travelling and quickly departed from this world. AKB 255 , sheet $46 \mathrm{v}$.

9 Another version of the diary, with a slightly different title (Historia fundaciej klasztoru nasze[go] wileńskie [go] ś[w]. Józepha przez Jaśnie Wielm[ożnego] J[ego] M[ości] Pana Stephana Paca podkanclerzego W[ielkiego] X[ięstwa] L[itewskiego] i matżonkę je[go] Maria Ancillę Rudominównę Dusiacka Pacowa fundowanego roku pański[ego] 1638), can be found on the final pages of Krótka kronika fundacji karmelitanek bosych klasztoru św. Józepha Wilnie, która stanęła roku 163818 Decembra. Originally deposited in the Archives of the Discalced Carmelite Nuns in Vilnius, the book is currently kept at the Archives of the Krakow Province of the Discalced Carmelite Order in Krakow (catalogue no. AKBW 22). Rewritten by two copyists, Sister Mary Magdalene's diary begins on page 333 and continues through page 362. The author of this study has compared both versions of the text (i.e the one from the Archives of the Discalced Carmelite Nuns in Wesoła Street, Krakow, and the one from the Krakow Province of the Discalced Carmelite Order in Krakow). The inconsistencies between the two versions are minor and bear no significant impact on the findings of this study. The existence of the latter copy was unknown to the previous scholars of St. Mary Magdalene’s diary, Rafał Kalinowski and Karolina Targosz. 
Seirijai, Prienai, Trokai) but also put down information that seemed of value to the nuns, for instance the churches in which they participated in the Mass. These brief visits gave Sister Mary Magdalene a pretext to write short descriptions of the temples and their interiors ${ }^{10}$. In one of such entries, she describes the church in Czemierniki, where the Carmelites stayed on November 17. After the Mass, they prayed at the altar of the Blessed Virgin Mary, which "held this beautiful painting, and having stayed there for a while, we entrusted ourselves to Our Queen and returned to the coach"11. Sister Mary Magdalene also mentioned a church in Białystok (visited on November 24), describing it as "a beautiful church, made of brick" She also provided a detailed outline of the Parish Church in Trokai, a famous Lithuanian sanctuary at which the nuns and their founders arrived on December 16, of which she wrote: "A beautiful, brick church, with a painting of the Blessed Virgin in the big altarpiece, adorned with many a votive offering in and outside of the altar. The painting of the Blessed Virgin Mary is both beautiful and miraculous. Many a man from different locations comes here to pray, as they do in Częstochowa, and receive the Blessed Virgin's blessings. [...] Their lordships [Lord and Lady Pac] led us to the church, and as we approached the altar, the painting of the Blessed Virgin was unveiled for us"13. As the nuns returned to the on the following day to participate in the morning Mass, "it was dark, and we found it difficult to access the church from above, as the ground was slippery, but with the help of Divine grace, we made it to the church safe and sound"14. The liturgy was celebrated "at the side altar [...] accompanied by songs and the organ"15.

The range of epithets used by Sister Mary Magdalene of Christ the Redeemer ${ }^{16}$ to describe the church edifices and their furnishings is meager at best. She was more interested in the circumstances of the Masses in which she participated: the relics and the miraculous

\footnotetext{
10 While travelling, the four nuns rarely participated in the Mass in church. In most cases, the Mass was celebrated by their fellow travelers, the monks of St. Theresa's Monastery in Vilnius, in the manors that lodged the group on their way to Vilnius.

11 AKB 255, sheet 48v.

12 AKB 255, sheet 54r.

13 AKB 255, sheet 79v.

14 AKB 255, sheet 81r. On a side note, the church is located on a rather steep hill, and as such continues to be somewhat difficult to access, especially in the winter.

15 AKB, sheet 81r.

16 Anna Żaboklicka was the daughter of a Sochaczew-based judge Andrzej and his wife Barbara (née Radomiecka). Anna took her vows at the age of 25, on April 11, 1633 in Lublin. Following her stay in Vilnius, where she served as a deputy prioress until May 11, 1645, she returned to her home cloister, where on January 26, 1648 she was appointed calvary. At the turn of 1648 and 1649, she stayed in Budzisław in the region of Kujavia, together with other nuns. On May 11, 1649, she returned to Lublin for the second foundation of the cloister, becoming its deputy prioress and, subsequently, its prioress (between 1661 and 1664). On October 11, 1665, Żaboklicka was sent to Poznań along with two other nuns, where between 1668 and 1674 she served as a prioress and supervised the construction of the new church and cloister. Aside from the diary discussed in this study, Żaboklicka's literary output also included a valuable hagiography of Sister Theresa Barbara of the Holy Sacrament (Teofila Zadzikowa née Kretkowska), published by Czesław Gil in 2013 as part of the "Źródła Karmelitańskie” book series. Sister Mary Magdalene of Christ the Redeemer was also an esteemed copyist and the initiator of the rewriting of a substantial part of the ascetic code of conduct compiled at the Poznań cloister. Kronika klasztoru..., op. cit., p. 77; Cz. Gil, Stownik polskich..., op. cit., pp. 60-61; idem, Karmelitanki bose..., op. cit., pp. 42, 78-79.
} 
paintings $s^{17}$, the churchgoers ${ }^{18}$, the musical setting ${ }^{19}$, and the situation of the pews in which the nuns were seated ${ }^{20}$. The diarist's limited range of vocabulary in this regard is hardly surprising, not only given her Carmelite background and lack of interest in the glitter of earthly life but also due to the fact that the language used to describe and interpret works of art in mid- $17^{\text {th }}$ century Poland was very narrow ${ }^{21}$. However, even considering the historical circumstances, Sister Mary Magdalene's command of Polish was nonetheless limited, even though the diary is pervaded by genuine commitment and joie de vivre resulting from her journey to a new outpost. Consequently, her diary radiates undeniable charm, continuing in the grain of the literary culture of Discalced Carmelite nuns, whose cloistral education involved not only reading but also writing devotional texts, including mystical autobiographies and poetry, as well as cloistral chronicles ${ }^{22}$.

Sister Mary Magdalene's diary provides a very detailed description of the celebrations held on December 19, 1638 on the occasion of the nuns' introduction to their Vilnius cloister ${ }^{23}$. The sisters reached the capital of the Grand Duchy of Lithuania two days earlier, accompanied by Carmelite monks, as well as the founders of the new convent and their entourage. After a ceremonial welcome at the-then wooden Church of St. Theresa, the nuns rested at the Pac Palace in St. John's Street. On the following day (December 18), “on Saturday before ten, our Lordships and the Reverend Fathers ordered us to accompany Her Lordship [Anna Maria Ancilla née Rudomina-Dusiatska] to the castle church, where St. Casimir lies, and led us to the chapel in which he lies. On entering the church, His Grace the Canon of Vilnius blessed us each with holy water. We went inside the chapel to hear the Mass, which began soon after [...]"24. "Having heard two Masses, we waited till the faithful and His Grace's servants left the chapel, while Her Lordship stayed with us. The Reverend Fathers told us to lift our veils and behold the chapel. St. Casimir lies at the altar, or rather, underneath the altar used for the celebration of the Mass. The altar has no antepedium save for brass lattice and ebony columns with white ivory, and a silver coffin which holds the saint. The Reverend Fathers opened the lattice and let us kneel before the altar, where we entrusted ourselves to the saint,

17 Having visited St. Theresa's Church in Vilnius (which was a wooden building at the time) on December 17 , Sister Mary Magdalene observed that the relic of Our Holy Mother St. Theresa was on display at the altar, in a monstrance-like feretory. AKB 255, sheet $81 \mathrm{v}$.

18 While in Białystok on November 24, we have heard two Masses and took communion, with Her Lordhisp, Wife of Grandmarshal of Lithuania [Aleksandra Marianna Wiesiołowska, related to the Deputy Chancellor of the Treasury of Lithuania's wife] also present at those Masses. AKB 255, sheet 54r.

19 At a service held on December 12 in a church in Prienai, the seat of the Starosty held by the Deputy Chancellor of the Treasury of Lithuania, the singers [...] of His Lordship [Stefan Pac] sang and played mightily and finely. AKB 255, sheet 73v.

20 The Mass at the church in Prienai on December 12 was celebrated at the side altar, in front of the pew in which we kneeled. AKB 255, sheet 74v.

21 For more on the subject, see a.o. H. Dziechcińska, Sarmaci wobec sztuki malarskiej. Na przykładzie pamiętników epoki, w: Corona scientiarum. Studia z historii literatury i kultury nowożytnej ofiarowane profesorowi Januszowi Palcowi, ed. J.A. Chrościcki, Warszawa 2004, pp. 356-359; J. Tazbir, Wrażliwość artystyczna szlachty polskiej, in: Cała historia to dzieje ludzi... Studia z historii społecznej ofiarowane profesorowi Andrzejowi Wyczańskiemu w 80-ta rocznice urodzin i 55-lecia pracy naukowej, ed. C. Kukla, Białystok 2004, pp. 55-64.

22 H. Popławska, Kultura literacka karmelitanek bosych w Polsce (XVII-XVIII wiek), Gdańsk 2006, pp. 10-20, 22-23, 26, 40-56.

23 See A.S. Czyż, op. cit., pp. 146-148.

24 Following this quote is a description of the nuns' confession, to which they went before visiting the Vilnius Cathedral. Since it bears no significance to the subject of this study, the said description has been skipped. 
and kissed the coffin. The altar is all silver and ebony, grand, stately, and costly. It bears large silver figures and a large crucifix, with the Blessed Virgin, St. John underneath, St. Casimir on one side, and St. Sigismund on the other, along with two more figures above it, with the Blessed Virgin and two angels at the top, all of them carved in silver. The chapel is laid with marble, grand and beautiful, and erected at a great [...] expense, tall and joyful, but unfinished on the outside, with the scaffolding still in place. On one side hangs a beautiful image of St. Casimir, which depicts his entire life. On the other side hangs an image of St. Sigismund, with more beautiful paintings above him, yet we could not see them through the scaffolding. Her Lordship invited us to see the old chapel of St. Casimir, in which he laid before. The old marble chapel was built at the expense of His Majesty Sigismund, may he rest in peace, before the current king [Władysław IV] moved [the feretory] to the new one. In the old chapel, where St. Casimir used to lie before, now lies His Grace Bishop of Vilnius [Eustachy Wołłowicz], uncle of Her Lordship [Anna Maria Ancilla née Rudomina-Dusiatska], who was strongly favorable to our order, and celebrated a Mass on our Reverend Fathers' arrival [in Vilnius in 1626]. Her Lordship told us that, had he lived to see our coming, it would have delighted him likewise. As we stepped inside the chapel, Her Lordship asked us to say a prayer in his intention, following which our Reverend Fathers told us to lift our veils and behold the chapel. It was beautiful, joyful, and tall, with a painting of the Blessed Virgin, and a marble floor. We proceeded to the sacristy, which adjoined the chapel and seemed capable and beautiful to our eyes, and passed through another one on the upper floor, which was just as beautiful, and as we came there, the canon who was our guide said a solemn prayer" 25 .

Organized at the behest of Lord and Lady Pac, the excursion of the Discalced Carmelites to the Vilnius Cathedral was intended to directly expose them and their entourage to two structures indirectly tied to the Deputy Chancellor of the Treasury. Stefan Pac supervised the erection and decoration of St. Casimir's sanctuary on behalf of the Polish king ${ }^{26}$. The redevelopment of the sepulchral chapel of Bishop Eustachy Wołłowicz ${ }^{27}$ (a close relative of Anna Maria Ancilla née Rudomina-Dusiatska), which began in 1627, was likely conducted

\footnotetext{
25 AKB 255, sheet 83r-84v.

26 The Chapel of St. Casimir was founded by King Sigismund III Vasa in 1623. The bulk of the work concluded in 1636, with complementary decorative work continuing throughout the 1640s. A flagship artistic enterprise of the first representative of the Vasa dynasty on the Polish-Lithuanian throne, the chapel has been described extensively in the literature on the subject, a.o. in P.J. Jamski, Ottarz relikwiarzowy w wileńskiej Kaplicy św. Kazimierza w pierwszej połowie XVII wieku, "Barok", 12/2005, no. 2, pp. 41-44; idem, Kaplica świętego Kazimierza w Wilnie i jej twórcy, "Biuletyn Historii Sztuki”, 68/2006, no. 1, p. 19; B.R. Vitkauskiené, Karaliaus Zigmanto Vazos užsakymai Vilniaus Žemutineje pilyje, "Dailès Istorijos Studijos. Kultūros, Filosofijos ir Meno Institutas", 2/2006, pp. 46-48.

27 The Chapel of the Immaculate Conception (formerly known as the royal chapel) has not attracted significant attention from researchers. Dating back to the reign of Kazimierz Jagiellończyk, it assumed its modern shape under Bishop Eustachy Wołłowicz, who chose it as his future mausoleum. The renovation began around 1625, with the bulk of the work finished by 1631. Aside from the chapel itself, art historians tend to gloss over the bishop's activity as a patron of arts. A thoroughly educated man, Wołłowicz was also known for his sophisticated artistic taste. He was also cognizant of the tremendous creative potential of art, as evidenced by the medals and graphics created under his auspices. See W. Zahorski, Katedra wileńska, Wilno 1904, pp. 120-125; M. Janicki, Willa Eustachego Wollowicza $w$ Werkach pod Wilnem i jej epigraficzny program ideowy, "Barok", 6/1997, no. 2, pp. 123-149; M. Kałamajska-Saed, Litewska Pietà Michała Anioła, in: Mowa i moc obrazów. Prace dedykowane profesor Marii Poprzęckiej, Warszawa 2005, p. 55-58; P.J. Jamski, Kaplica świętego Kazimierza..., op. cit., pp. 21, 33; M. Jarczykowa, ,, Heretycki biskup” - Eustachy Wołlowicz w kręgu Radziwiłłów birżańskich, "Wschodni Rocznik Humanistyczny", 4/2007, pp. 53-65.
} 
by the same team of artists that worked on the original burial place of St. Casimir. The said artists were also involved in other works founded by the Pac family ${ }^{28}$.

The visited venues - in particular the Chapel of St. Casimir - left an indelible impression with Sister Mary Magdalene, as they no doubt did with her fellow nuns. In an entry to her diary, the Carmelite gave a detailed description of the sanctuary, beginning with its highlight, i.e. the altar with the feretory. The relic of St. Casimir was placed underneath the altar top, supported by ebony columns decorated with ivory appliqué. The silver feretory could be seen through a double brass lattice that was opened in the presence of guests of honor. Underneath the altar top stood an ebony-and-silver altarpiece. The nun described it as grand, and as the historical data goes to show, it was indeed a tri-axial and two-story structure crowned with a top piece. Its lower part featured a crucifix with the silver figures of the Virgin Mary and St. John. On the side axes stood the figures of St. Casimir and St. Sigismund. The second story was furnished with two more silver figures, which the nun failed to detail. According to the diarist, the top piece featured a sculpture of the Virgin Mary and two angels.

The second-story figures left unnamed in Sister Mary Magdalene's diary were those of St. Peter and St. Paul, according to other descriptions of the sanctuary ${ }^{29}$. Her description of the top piece, however, is a dubious one, given that the anonymous Jesuit who detailed the altarpiece in 1636, wrote of a "Christi triumphantis icon [...] et hinc inde duo angeli" 30 . Considering that Sister Mary Magdalene failed to mention either the silver bass-relief of Jerusalem behind the cross, or the dove of the Holy Spirit ${ }^{31}$, while also leaving out the identity of the sculptures on the second story of the altarpiece, she may have been mistaken on account of their positioning above her line of sight and, most likely, against the background of a window.

Having eulogized the chapel, its spacious and bright interior, and its rich marble lining, Sister Mary Magdalene concluded that "its top was unfinished, with the scaffolding still standing". The said scaffolding, which enabled the artists to work on the decorations above the cornice, perhaps on the inner walls of the dome, obscured the sight of the paintings situated in the upper parts of the walls. The nun described those as quite beautiful. She was even more positive with respect to the paintings of the lives of St. Casimir and St. Sigismund. Positioned in the recesses of the side walls, and unobstructed by the scaffolding, the two paintings were dubbed very beautiful.

Until now, Sister Mary Magdalene's has been the sole surviving mention of the paintings inside the Chapel of St. Casimir (and their subject matter) that we know of. The paintings tapped into the dynastic and propagandist messages articulated inside the edifice, while also responding to the prevalent interest in hagiography and the widespread cult of the saints of yesteryear at the time. The decorations mentioned and fancied by Sister Mary Magdalene were

\footnotetext{
28 For more on the subject, see A.S. Czyż, op. cit., pp. 73-81, 124-125.

29 Seminal descriptions of the Chapel of St. Casimir were written in 1636 by an unknown Jesuit priest, and in 1698 by the chapel's parish priest, Mikołaj Zgierski, respectively. Zgierski made an inventory of the original altar based on eye-witness testimonies. See P.J. Jamski, Ottarz relikwiarzowy..., op. cit., pp. 53-54; B.R. Vitkauskienė, Karaliaus Zigmanto..., op. cit., pp. 58-60; eadem, Złotnictwo wileńskie. Ludzie i dzieła XV-XVIII wiek, Warszawa 2006, pp. 191-192.

30 As cited in B.R.Vitkauskienè, Zlotnictwo..., op. cit., p. 192.

31 P.J. Jamski, Ottarz relikwiarzowy..., op. cit., pp. 53-54.
} 
made at the turn of 1635 and 1636 by Bartholomeus Strobel, hired by King Władysław IV, who subsequently awarded him with Polish peerage in $1639^{32}$.

Another relevant source on the Chapel of St. Casimir - a settlement issued to Piotr Nonhardt by the Lithuanian Deputy Chancellor of the Treasury Stefan Pac in 1631, mentions the paintings of "eight major angels" and an image of the "Smolensk Castle" 33 . It is difficult to prove that the lower paintings of inferior quality, referenced by Sister Mary Magdalene, are the figures of angels mentioned in the 1631 document. Due to their size, these figures were unlikely to have been accommodated in the eight panels situated underneath the recesses, which became home to the wooden, silver-plated figures of the monarch saints. Perhaps it was there - or in the panels below - that a gallery of the Jagiellonian and Vasa victories was projected, showcasing the images of the cities conquered by the Polish rulers, and thus adding to the dynastic and propagandist ambience of the Chapel of St. Casimir. It would be all the more desirable considering the fact that at least some of those victories were won under the patronage of the canonized prince ${ }^{34}$.

The nuns concluded their deluxe tour of the Vilnius Cathedral at the chapel that had originally held the body of the deceased Jagiellonian. The nuns visited the former royal chapel, transferred in 1623 to Bishop Eustachy Wołłowicz (d. 1630) in return for the chapel of Bishop Paweł Holszański and the empty place next to it, at the request of Anna Maria Ancilla Pac. Encouraged by the wife of the Deputy Chancellor, they said a prayer for the respite of her uncle's soul, likely at the bishop's tomb (unmentioned in Sister Mary Magdalene's diary). ${ }^{35}$ The diarist once more pointed to the bright interior of the chape ${ }^{36}$. As indicated by its appellation, the chapel's altarpiece contained a painting of the Virgin Mary. Sister Mary Magdalene also mentioned its marble floor, possibly imported from the Swedish isle of Öland. Adjoining the chapel was a spacious and beautiful sacristy.

The idea of Lord and Lady Pac to showcase the Chapels of St. Casimir and of the Immaculate Conception from among the numerous monuments of Vilnius and its Cathedral for the arriving Discalced Carmelite nuns and the monks that accompanied them demonstrates that they never missed an opportunity to cast their family in a an appropriate light. At the same time, if not more importantly, the discussed description of the two chapels, featured in Sister Mary Magdalene's 1638 diary is a testament to the tremendous adoration towards St. Casimir at the time, along with the awe-inspiring sanctuary founded in his honor by King Sigismund III.

Cited for the first time in the literature on the subject, the above excerpt from the chronicle of the Discalced Carmelite nuns also corroborates (and sheds a new light on) several missing

\footnotetext{
32 J. Tylicki, Barttomiej Strobel. Malarz epoki wojny trzydziestoletniej, vol. 1, Torun 2000, p. 84-86, 415-416; vol. 2, p. 55. Another painter, Giacinto Campana, was hired to work on the chapel in 1639. See K. Mikocka, Nowe materialy dotyczace budowy i kaplicy św. Kazimierza w Wilnie, "Kwartalnik Architektury i Urbanistyki", 26/1981, no. 3/4, pp. 237, 239; P.J. Jamski, Kaplica świętego Kazimierza ..., op. cit., pp. 35-36.

33 For a reprint of the original source from the Pac Archives, accompanied by a detailed and intriguing study, see P.J. Jamski, Kaplica świętego Kazimierza ..., op. cit., p. 41.

34 The said victories included the battles of Orsza (1514) and Polotsk (1518), the defeat of Tzar Vasil III (1519), the captures of Smolensk (1611) and Khotyn (1624). K. Moisan-Jabłońska, Obrazowanie walki dobra ze złem, Kraków 2002, pp. 295-297; P.J. Jamski, Kaplica świętego Kazimierza ..., op. cit., p. 36.

35 W. Zahorski, op. cit., pp. 124-125; M. Matušakaitè, Išejusiems atminti. Laidosena ir kapu ženklinimas LDK, Vilnius 2009, pp. 181-183.

36 W. Zahorski, op. cit., pp. 122-123.
} 
bits of information on the furnishings of the Chapel of St. Casimir prior to the Battle of Vilnius and the subsequent plunder of the Lithuanian capital in 1655. Above all, however, it should be stressed that - similarly to the other existing sources - Sister Mary Magdalene's account corroborates that the decorative works in the chapel were still under way in 1636, following the translation of St. Casimir's body. The recess for the feretory, located underneath the altar top, was supported by ebony columns, whose stems were decorated with white plaques. The feretory was, indeed, shielded by a lattice structure, but it was not made of silver. These two details complement the comprehensive reconstructive study of the altarpiece, conducted by Piotr J. Jamski ${ }^{37}$.

It is especially important to determine the subject matter of Bartholomeus Strobel's paintings, and their positioning on the side walls of the chapel. It also seems noteworthy that Sister Mary Magdalene failed to mention the luxurious silver decorations and furnishings inside the chapel, including its minor altars, perhaps because they may have been added after $1638^{38}$.

Contrary to the copious research on the Chapel of St. Casimir, the studies on the Chapel of the Immaculate Conception are few and far between. One is tempted to think that the fact that Sister Mary Magdalene described the latter using virtually the same words as she did with the Chapel of St. Casimir (whose design is often attributed to Constantino Tencalla ${ }^{39}$ ) suggests their compositional affinity, if not the same authorship. To state this affinity indisputably, however, requires further research. For now, the matter remains open for debate.

\section{Chapels of St. Casimir and the Immaculate Conception at the Vilnius Cathedral as seen by Carmelite nuns: an unrecognized source from 1638 Summary}

The article recalls a source from 1638 which has hitherto not been referred to in the literature on the subject, i.e. the history of two chapels at the cathedral in Vilnius: the Chapel of St. Casimir founded by King Sigismund III, and the Chapel of the Immaculate Conception, furnished as a burial chapel by Bishop Eustachy Wołłowicz (lit. Eustachijus Valavičius). The said source is a diary written by a Carmelite nun during her journey from Lublin to Vilnius (14 November - 26 December 1638), which she made with three fellow nuns assigned to a new monastery founded by Stefan Pac (lit. Steponas Pacas) and his wife Anna Maria Ancilia née Rudomina-Dusiatska (lit. Ona Marija Ancilia Rudomina-Dusiackaitė). The diary was penned by Sister Mary Magdalene (Anna Żaboklicka) who described various aspects of their journey, as well as a visit to the Vilnius Cathedral organized by the Pac family. The nuns were particularly impressed by the Chapel of St. Casimir. Thanks to Sister Mary

\footnotetext{
37 P.J. Jamski, Ottarz relikwiarzowy..., op. cit., pp. 53-54, 58.

38 P.J. Jamski, Kaplica świętego Kazimierza..., op. cit., p. 25. Jamski contends that the silver decorations, including the two minor altars, were added gradually, starting in 1627.

39 For more on the attribution disputes surrounding the chapel's origin, see a.o. M. Morelowski, Zagadnienie twórcy kaplicy św. Kazimierza i kościoła św. Teresy w Wilnie a Constantino Tencalla projektodawca kolumny Zygmunta III w Warszawie, "Prace i materiały sprawozdawcze sekcji historii sztuki", 2/1935, pp. 302-303; M. Karpowicz, Matteo Castello. Architekt wczesnego baroku, Warszawa 1994, pp. 73-78; H. Samsonowicz, Kaplica św. Kazimierza w Wilnie i uroczyste przeniesienie relikwii świętego w 1636 roku, w: Sztuka ziem wschodnich Rzeczypospolitej XVI-XVIII w., ed. J. Lileyko, Lublin 2000, pp. 335-336; P.J. Jamski, Kaplica świętego Kazimierza ..., op. cit, pp. 19, 27-30.
} 
Magdalene's detailed description of the chapel, it was possible to reconstruct the subjects of some paintings by Bartłomiej Strobel, and to interpret several facets of its appearance, including the feretory of St. Casimir. While the description of Bishop Eustachy Wołłowicz's chapel is not as detailed, it should be stressed that by inviting the nuns there, the Pac family intended to emphasize their kinship with the ruler of Vilnius, who was highly esteemed by his contemporaries.

Keywords: Vilnius, Chapel of St. Casimir, Chapel of the Immaculate Conception, Pac family, Carmelite nuns

Note on the Author: dr hab. Anna Czyż is an art historian specializing in early modern history, with a specific focus on the art of the Grand Duchy of Lithuania, artistic and formal problems, artistic foundations and propaganda in a broad cultural and historical context. She also catalogues the monuments of Polish church and sepulchral art in the former Eastern Borderlands (Ukraine, Lithuania) and the USA. 